\title{
Atlantic salmon paramyxovirus (ASPV) infection contributes to proliferative gill inflammation (PGI) in seawater-reared Salmo salar
}

\author{
Agnar Kvellestad ${ }^{1,2, *}$, Knut Falk ${ }^{2}$, Solveig M. R. Nygaard ${ }^{3}$, Kjell Flesjå4 , \\ Jan Arne Holm ${ }^{5}$ \\ ${ }^{1}$ Department of Basal Medicine and Aquatic Sciences, Norwegian School of Veterinary Science, PO Box 8146 Dep., \\ 0033 Oslo, Norway \\ ${ }^{2}$ National Veterinary Institute, PO Box 8156 Dep., 0033 Oslo, Norway \\ ${ }^{3}$ Fish Health and Environment Company, Ramsvollsveien 1, 5518 Haugesund, Norway \\ ${ }^{4}$ National Veterinary Institute, PO Box 295, 4303 Sandnes, Norway \\ ${ }^{5}$ Fjord-Lab AS, PO Box 7, 6701 Måløy, Norway
}

\begin{abstract}
Proliferative gill inflammation (PGI) causes significant losses in farmed Atlantic salmon Salmo salar L. in Norway, especially during the first months following seawater transfer. The aetiology is apparently multifactorial, including infection with chlamydia-like bacteria and Atlantic salmon paramyxovirus (ASPV). In the present study, gills from diseased fish from 3 farms on the western coast of Norway were sampled. The pathological changes were briefly described and the aetiological significance of ASPV studied by immunofluorescent staining of cryosections and by immunohistochemistry on sections of formalin-fixed and paraffin-embedded tissue. The pathological changes were macroscopically characterized by palour of the gills, and histologically by inflammation, circulatory disturbances, cell death and epithelial cell proliferation. ASPV was demonstrated in fish from all farms studied, as immunostaining consistent with ASPV was obtained in lamellar epithelial and endothelial cells of pathologically altered tissues. It is concluded that ASPV is at least a contributing cause of PGI. As far as we know, this is the first demonstration of fish disease related to infection with a paramyxovirus.
\end{abstract}

KEY WORDS: Atlantic salmon · Salmo salar · Proliferative gill inflammation · PGI · Epitheliocystis · Atlantic salmon paramyxovirus $\cdot$ ASPV $\cdot$ Immunofluorescence $\cdot$ Immunohistochemistry

- Resale or republication not permitted without written consent of the publisher

\section{INTRODUCTION}

Proliferative gill inflammation (PGI) denotes a disease of seawater-reared Atlantic salmon Salmo salar L. in Norway. PGI is not a notifiable disease and estimates of losses for the entire industry are not available. According to diagnostic investigations by local fish health services and the National Veterinary Institute, the disease has been present since the 1980s and occurs in all coastal regions where salmon farming is carried out. It occurs especially during the autumn and is an important cause of loss related to mortality and reduced growth rate in fish transferred to seawater the previous spring. Outbreaks may last for months
(Nygaard \& Flesjå 1997, Nygaard 2000). Extrapolations from diagnostic investigations in the county of Møre og Romsdal in 2003 indicate that approximately 150 farms in Norway may have been affected by PGI that year (Kvellestad et al. 2004).

Histological examinations of gills indicate a multifactorial aetiology of PGI. Epithelial cell inclusions (i.e. epitheliocysts) with chlamydia-like bacteria (Hoffman et al. 1969, Nylund et al. 1998, Draghi et al. 2004) are frequently but inconsistently seen in large numbers, suggesting that this agent is at least associated with the disease. Thus, this disease has often been termed 'epitheliocystis'. Although protozoan ectoparasites such as trichodinids and Ichthyobodo necator-like 
parasites may also be inconsistently observed at gill surfaces (Kvellestad et al. 2004), their role as primary aetiological factors is doubtful. Recently, a previously unknown virus, Atlantic salmon paramyxovirus (ASPV), was isolated from the gills of fish with PGI (Kvellestad et al. 2003), suggesting a possible viral involvement in development of this disease. However, due to the fact that the above-mentioned agents are inconsistently detected and their aetiological significance has not been fully investigated, we currently use the descriptive term 'proliferative gill inflammation' for this disease in order to reflect the unsolved aetiology.

This paper briefly describes the gill pathology of PGI as it occurred in fish selected from 3 seawater farms. A rabbit hyperimmune serum against ASPV was produced, characterized and used to detect viral antigen in gills by an indirect immunofluorescence (IIF) test on cryosections and immunohistochemistry (IHC) on sections of formalin-fixed and paraffin-embedded tissue.

\section{MATERIALS AND METHODS}

Virus and cell cultures. ASPV from the third to fifth passages (Kvellestad et al. 2003) was used. Rainbow trout gill (RTgill-W1) cells (Bols et al. 1994, ATCC CRL2523) were grown at $14^{\circ} \mathrm{C}$ in Leibovitz L-15 supplemented with $5 \%(\mathrm{v} / \mathrm{v})$ foetal bovine serum, $2 \mathrm{mM} \mathrm{L-}$ glutamine and $24 \mu \mathrm{g} \mathrm{ml} \mathrm{m}^{-1}$ gentamicin. Cells were incubated at $14^{\circ} \mathrm{C}$ after inoculation with virus without removal of the inoculum.

Production of polyclonal anti-ASPV serum in rabbit. Virus for immunization of rabbit was propagated and purified by $\mathrm{CsCl}$ gradient as previously described (Kvellestad et al. 2003) and resuspended in phosphate buffered saline (PBS; 10 mM, pH 7.2). Protein concentration was measured using a commercial assay (BioRad Laboratories) with bovine serum albumin serving as standard. Antigen preparation mixed with Freund's adjuvant was injected subcutaneously into a rabbit at multiple sites, 3 times at $4 \mathrm{wk}$ intervals. The first injection consisted of $100 \mu \mathrm{g}$ in complete adjuvant and the last 2 injections of $50 \mu \mathrm{g}$ in incomplete adjuvant. The rabbit was bled 2 wk after the last injection.

Testing of anti-ASPV serum by IIF staining of ASPV-infected cell cultures. Binding of anti-ASPV serum to ASPV antigen was tested in a cross-titration assay in 96-well microtitre plates essentially as described by Falk \& Dannevig (1995). The cultures were inoculated with different virus dilutions, incubated for 7 or $14 \mathrm{~d}$, assessed for cytopathic effects (CPE) by phase-contrast light microscopy, washed in PBS, fixed for $20 \mathrm{~min}$ in $80 \%$ (v/v) aqueous acetone, air dried, blocked for $30 \mathrm{~min}$ with $5 \%(\mathrm{w} / \mathrm{v})$ non-fat dry milk in PBS, incubated for $1 \mathrm{~h}$ with anti-ASPV serum dilutions (2-fold serial in PBS, 1:200 to 1:25600), and incubated for $1 \mathrm{~h}$ with fluorescein isothiocyanate conjugated goat antiserum against rabbit IgG (Southern Biotechnology Associates) diluted 1:50 in PBS with $0.5 \%$ non-fat dry milk. PBS with $0.1 \%$ (v/v) Tween 20 was used for washing before and after adding secondary antibody. Propidium iodide was added for nuclear staining, and all incubations were performed at room temperature. The cultures were examined using an inverted epifluorescent microscope (Leitz DMIL) with a $50 \mathrm{~W}$ mercury lamp. Controls included staining with anti-ASPV serum applied to non-infected cells, and preserum applied to infected cells with CPE, both 2-fold serially diluted 1:25 to 1:3200.

Characterization of anti-ASPV serum by virus neutralization. Anti-ASPV serum inactivated at $45^{\circ} \mathrm{C}$ for 30 min was tested for the ability to neutralize ASPV. Dilutions of serum (5-fold serial) and virus (2-fold serial) in cell culture medium were mixed to obtain all combinations of final serum dilutions of $5 \times 10^{-2}$ to $5 \times 10^{-5}$ and virus concentrations of $10^{2.7}, 10^{2.9}$ and $10^{3.3} \mathrm{TCID}_{50} \mathrm{ml}^{-1}$. The mixtures were incubated for $2 \mathrm{~h}$ $20 \mathrm{~min}$ at room temperature, followed by inoculation into 4 replicates of RTgill-W1 cells in 96-well microtitre plates. CPE were assayed by phase-contrast light microscopy at $48 \mathrm{~d}$ post inoculation (p.i.).

Characterization of immune serum by haemagglutination inhibition testing. Detection of haemagglutinating activity units (HAU ml-1) was carried out as previously described by Falk et al. (1997). The haemagglutination inhibition test was performed by first mixing $25 \mu \mathrm{l}$ of anti-ASPV serum (2-fold serially diluted in PBS, $1 \times 10^{-1}$ to $9.8 \times 10^{-5}$ ) with $25 \mu$ virus

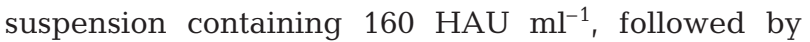
incubation for $1 \mathrm{~h}$. Fifty $\mu$ l of $0.5 \%$ (v/v) chicken red blood cells in PBS was then added and the agglutination endpoint read after $1 \mathrm{~h}$ of incubation. All incubations were performed at room temperature.

Field sampling of fish gills. Gills were sampled from Atlantic salmon transferred the previous spring to netpens in 3 seawater farms on the western coast of Norway. Farms 1 and 2 were situated in brackish water and Farm 3 in full-strength seawater.

Farm 1 harboured fish of 3 different generations, and during the last week of July a loss of appetite in all groups and a minor increase in mortality in a netpen with fish at $2.5 \mathrm{~kg}$ was reported. Two weeks later fish in the postsmolt group displayed signs of respiratory distress, and the cumulative mortality reached $40 \%$ over the next 3 mo. The most common gross pathology identified among postsmolt consisted of swollen, grayish, mucinous gills, sometimes combined with a pale liver with scattered bloody spots. Histological examination of gills, heart, liver, pancreas and pyloric ceca, 
kidney, skin and muscle revealed PGI, many epitheliocysts in gills and foci of necrosis in the liver. No bacteria were detected on blood agar plates (blood agar base with $5 \%$ bovine blood, 0.5 and $2 \% \mathrm{NaCl}$ ) ) which had been inoculated with material from anterior kidney of 13 dead and moribund fish and incubated at $20^{\circ} \mathrm{C}$. Mean water temperature decreased from $17^{\circ} \mathrm{C}$ in August to $12^{\circ} \mathrm{C}$ in September. Postsmolts in Farms 2 and 3 displayed similar gill histological changes and mortality.

In all farms, the gills were sampled from fish with clinical signs and weighing 90 to $540 \mathrm{~g}$. The fish were killed with a blow to the head and exsanguinated. Parallel samples of gill tissue from each fish were fixed in formalin $(10 \%(\mathrm{v} / \mathrm{v})$ in $135 \mathrm{mM}$ sodium phosphate buffer, $\mathrm{pH}$ 7.0) or frozen on dry ice and stored at $-70^{\circ} \mathrm{C}$.

IIF staining of cryosections of gills. Cryosections of gills stored at $-70^{\circ} \mathrm{C}$ were fixed in $100 \%$ acetone for $10 \mathrm{~min}$ and IIF stained with preserum (diluted 1:1000 and 1:2000) and anti-ASPV serum (2-fold serially diluted $1: 1000$ to $1: 256000$ ), according to the protocol described above for cultured cells, but without nuclear staining.

Histology and IHC. Gills fixed in formalin for $3 \mathrm{~d}$ or more were dehydrated in graded ethanols, cleared in xylene and embedded in paraffin, according to standard protocols. Approximately $5 \mu \mathrm{m}$ thick sections of gill filaments and lamellae were heated on slides at $60^{\circ} \mathrm{C}$ for $20 \mathrm{~min}$, dewaxed in xylene and rehydrated through graded ethanols. Rehydrated sections were stained with haemalum and eosin for the study of morphology, with Perl's Prussian Blue reaction for ferric iron (Stevens 1990), and (on poly-L-lysine coated slides) according to the IHC procedure described below.

Preserum and anti-ASPV serum for IHC were adsorbed against acetone powder made according to Harlow \& Lane (1988) from gills of healthy fish. The sera were diluted to working dilution (1:1000) in PBS containing $1 \%(\mathrm{w} / \mathrm{v})$ acetone powder, incubated for $60 \mathrm{~min}$ at room temperature and cleared by centrifugation. Bovine serum albumin was added to the supernatant to $2.5 \%$ (w/v).

Antigens were unmasked essentially as described by Shi et al. (1993) on rehydrated sections in citrate buffer (10 mM citric acid, pH adjusted to 6.0 with $\mathrm{NaOH}$ ) by boiling for $2 \times 6 \mathrm{~min}$ in a microwave oven and after each heating left in the warm solution for 5 and $15 \mathrm{~min}$, respectively.

Further procedures were essentially the same as those described by Hsu et al. (1981) and Evensen (1993), and were performed at room temperature, unless otherwise stated. Briefly, sections were washed in Tris-buffered saline (TBS; Tris- $\mathrm{HCl} 50 \mathrm{mM}, \mathrm{NaCl}$ $150 \mathrm{mM}, \mathrm{pH}$ 7.6) with $0.05 \%$ (v/v) Tween 20, incu- bated for 20 min with blocking solution $(2 \%$ [v/v] normal goat serum and $5 \%$ [w/v] non-fat dry milk in distilled water), tilted to remove blocking solution, incubated overnight at $4^{\circ} \mathrm{C}$ with primary antibody (preserum and anti-ASPV serum diluted 1:1000), washed in TBS with Tween 20, incubated for $30 \mathrm{~min}$ with secondary antibody (biotinylated anti rabbit IgG [Vectastain ${ }^{\circledR}$ ABC kit, AK 5001, Vector Laboratories] diluted 1:200 in distilled water with $1 \%$ [w/v] non-fat dry milk), washed in TBS with Tween, incubated for 30 min with streptavidin-biotin alkaline phosphatase (Vectastain ${ }^{\circledR}$ ABC kit) diluted 1:100 in distilled water, washed in TBS with Tween, incubated for $15 \mathrm{~min}$ in developing solution (2.0 mg naphthol AS-MX phosphate, $0.2 \mathrm{ml} \mathrm{N}$,N-dimethylformamide, $0.01 \mathrm{ml} 1.0 \mathrm{M}$ levamisole and $10 \mathrm{mg}$ Fast red TR [all Sigma] in $9.8 \mathrm{ml}$ TBS, pH 8.2). Sections were washed in tap water before being counterstained with haemalum for $5 \mathrm{~min}$ and finally mounted in polyvinyl alcohol.

Controls included IHC staining with anti-ASPV serum as described above, with serially diluted serum on sections of ASPV-infected gill, and with 1:1000 dilutions of preserum and anti-ASPV serum on tissue sections from fish with extensive pathological changes due to infections with viral haemorrhagic septicemia virus (VHSV), infectious haematopoietic necrosis virus (IHNV), infectious pancreatic necrosis virus (IPNV) serotype $\mathrm{Sp}$ and infectious salmon anaemia virus (ISAV).

For additional controls, polyclonal rabbit antibodies against VHSV and IPNV, and monoclonal antibodies against IHNV, were applied both to sections containing ASPV and to sections containing homologous virus, essentially as described by Evensen et al. (1994), Evensen \& Rimstad (1990) and Brudeseth et al. (2002), respectively. Rabbit polyclonal antibody against ISAV (Falk et al. 1997) was applied to sections containing ASPV and ISAV according to the procedure for detection of ASPV described above.

\section{RESULTS}

\section{Testing and characterization of anti-ASPV serum}

Binding of anti-ASPV serum to ASPV antigens was demonstrated. IIF staining of ASPV-infected cell cultures incubated for 7 and $14 \mathrm{~d}$ p.i., in which CPE were detected by phase-contrast light microscopy in wells infected with the highest virus doses, showed fluorescence from the cytoplasm of cells in all infected wells and with all dilutions of anti-ASPV serum applied (Fig. $1 \mathrm{a}-\mathrm{c}$ ). The intensity of the fluorescent reaction and the number of fluorescing cells decreased with decreasing inoculation dose of virus, and in wells in- 

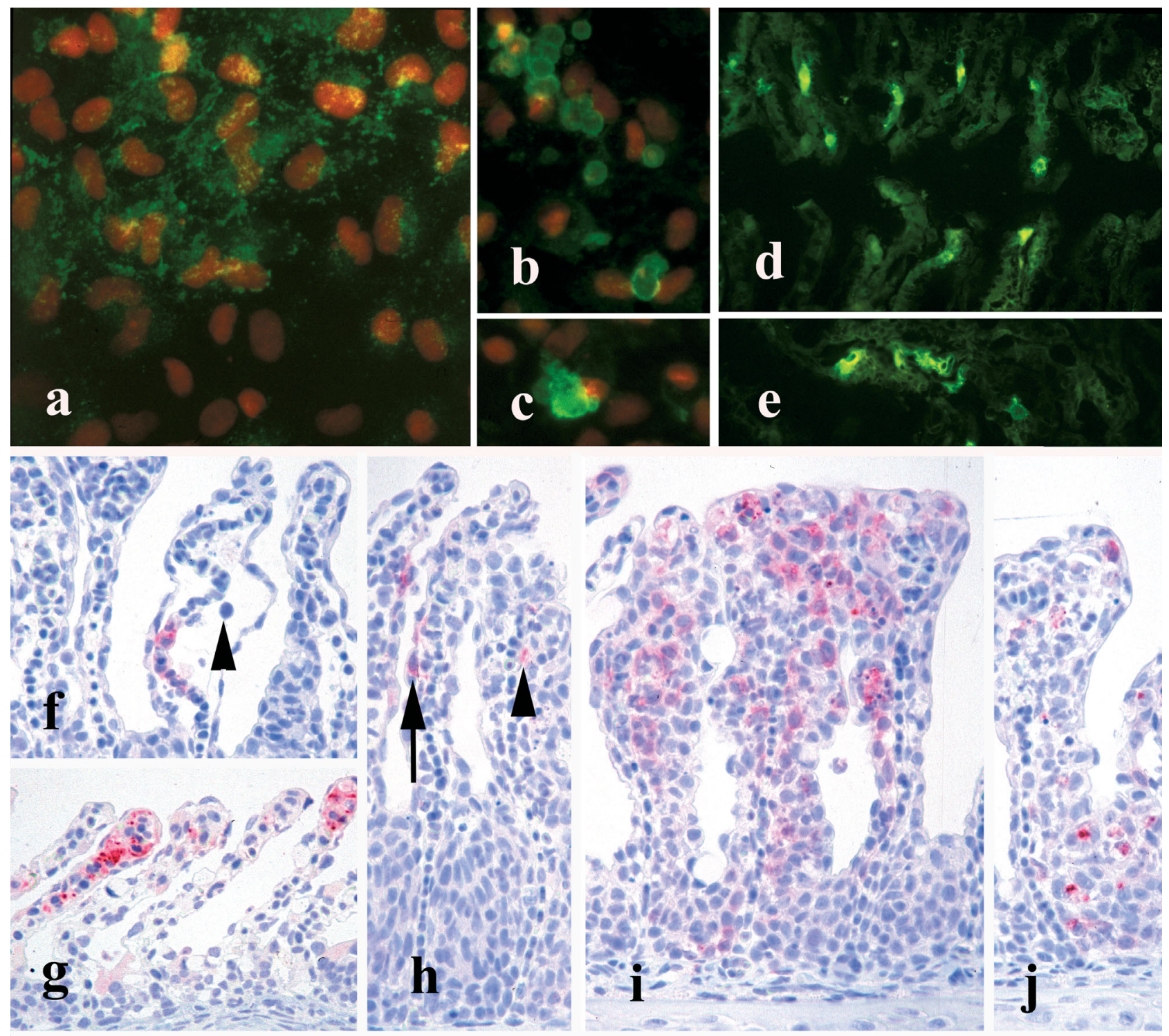

Fig. 1. Salmo salar L. Detection of Atlantic salmon paramyxovirus (ASPV) by immunostaining in infected cultures of RTgill-W1 cells and in sections from gills of $S$. salar suffering from proliferative gill inflammation (PGI). (a-e) Detection of ASPV in cultures and cryosections by indirect immunofluorescence staining. (a-c) Cultures incubated for (a) 7 and (b,c) $14 \mathrm{~d}$ post inoculation before staining. Nuclei are red, $\times 325$. (a) Extensive fluorescence from many small and partly coalescing particles in the cytoplasm and apparently also in the plasma membrane of cells in a focus surrounded by cells with no detectable fluorescence. (b,c) Fluorescence from inclusions or apparently all parts of the cytoplasm of shrunken cells. (d,e) Gill cryosection with extensive fluorescence in cytoplasm of lamellar cells, $\times 170$. ( $\mathrm{f}-\mathrm{j})$ Detection of ASPV by immunohistochemical examination of sections from formalin-fixed and paraffin-embedded tissue, $\times 280$. (f) Staining of endothelial (pillar) cell cytoplasm in a lamella with oedema and a few inflammatory cells (arrowhead) in the epithelium. (g) Extensive staining of cells in the lamellar vascular system, especially towards apical margins where the vessels were dilated and the endothelial cells apparently dead, as no normal vascular structure could be observed. (h) Staining of cytoplasm in epithelial cells (arrow) and of cells in an area with inflammatory cells (arrowhead). (i) Extensive staining of cells in epithelium with many inflammatory cells and hyperplasia of apparently poorly differentiated epithelial cells. (j) Staining of cytoplasmic inclusions in cells in hyperplastic epithelium

oculated with the lowest doses the positive cells were observed in clusters surrounded by large areas of cells showing no fluorescence. Fluorescence from nuclei was never observed. The anti-ASPV serum could be diluted up to 1:6400 without any significant loss in fluorescence intensity from cells incubated for $7 \mathrm{~d}$. A slight diffuse unspecific cytoplasmic fluorescence was present in uninfected cells up to 1:3200 dilution of anti-ASPV serum. No fluorescence was observed in infected cells to which preserum was applied. 
Anti-ASPV serum dilutions up to 1:10 240 and 1:5120 neutralized virus infectivity at titres of $10^{2.7}$ and $10^{2.9}$ to $10^{3.3} \mathrm{TCID}_{50} \mathrm{ml}^{-1}$, respectively. Serum dilutions up to 1:2560 inhibited the agglutination of chicken erythrocytes by a virus amount of $80 \mathrm{HAU} \mathrm{ml}^{-1}$. The results indicate binding of anti-ASPV serum to the haemagglutinin present at the surface of virions and infected cells.

\section{Pathology}

Pathologic changes of the same type (Fig. 2) were detected in gills of all fish from the 3 farms, although with great individual variation. Briefly, the gills were macroscopically pale. Histologically, erythrocytes and inflammatory cells were seen inside and/or outside the central venous sinus of the filaments. The latter included macrophages phagocytosing erythrocytes and accumulating ferric iron, as demonstrated by Perl's Prussian blue reaction.

Lamellar vascular changes included blood accumulation in lumina and/or haemorrhages and/or thrombosis and death of endothelial (pillar) cells. In the epithelium we observed death of epithelial cells, proliferation of apparently poorly differentiated epithelial cells especially in the interlamellar epithelium, and infiltration with inflammatory cells. In some lamellae there was a clearly positive correlation between organization of thrombi and epithelial hyperplasia. Ferric iron was also demonstrated in macrophages phagocytosing erythrocytes in the lamellar epithelium. Varying numbers of epitheliocysts, trichodinids and Ichthyobodo necator-like parasites were also seen. The changes occurred segmentally or along the whole length of the filaments, and the lamellar changes frequently resulted in thickening of the apical margin.

\section{Indirect immunofluorescence staining of tissue sections}

The gills of 1 fish (Fish 335, Farm 1) with few epitheliocysts, but extensive vascular changes presumptively induced by viral infection were selected in order to test anti-ASPV serum.

The preservation of tissue morphology was not optimal, but fluorescence was observed in the cytoplasm of a moderate number of lamellar cells, apparently both in the epithelium and in the vascular system (Fig. 1d,e), and in a very few cells apparently located in the central venous sinus endothelium. The majority of fluorescing cells were clustered within single lamellae or groups of lamellae. The fluorescence was either homogenous from all parts of the cytoplasm, was partly granular, or occurred from a few very small granules. Staining of nuclei was never observed. Non-specific fluorescence was eliminated by dilution of anti-ASPV serum to 1:1000. Specific cytoplasmic fluorescence was extensive, moderate and slight at dilutions up to 1:8000, 1:32 000 and 1:64 000, respectively, and not observed at higher dilutions. No fluorescence was observed in sections stained using preserum as primary antibody.

Gills from other individuals and with histological changes suspected to have been induced by viral infection were then stained with anti-ASPV serum diluted 1:2000 and with sections from Fish 335 used as controls. Preserum and anti-ASPV serum were applied to the control sections. Weaker specific fluorescence as described above for Fish 335 was observed in gills from a number of these fish (Table 1).

\section{Immunohistochemistry}

The anti-ASPV serum gave strong reactions in the cytoplasm of lamellar endothelial and epithelial cells, and possibly also in inflammatory cells in the epithelium of many lamellae when applied to sections from Fish 335 (Fig. 1f-j). The reaction became slight when the antiASPV serum was diluted 1:10 000 and 1:100 000 and absent at higher dilutions. The preserum gave no reaction.

Gills from all fish examined by IIF were then examined by IHC. Gills from Fish 335 were used as controls. Fish displaying positive reactions in gills with pathologic changes as described above were seen in all farms (Table 1). In a few fish, staining of few endothelial cells of the central venous sinus was also observed. Individual unspecific reactions varied from slight to moderate, and were seen especially in chloride cells, indicating reactions to mitochondria. Apparently, no correlation existed between the detection of ASPV by immunostaining and epitheliocysts by haemalum and eosin staining, as none, one or both agents were detected in one and the same fish.

No cross-reactions were observed, as specific antibodies to ASPV, VHSV, IHNV, IPNV and ISAV reacted with homologous virus only.

\section{DISCUSSION}

In this study we have briefly described the pathological gill changes of PGI in seawater-farmed Atlantic salmon in Norway. The changes described, i.e. circulatory disturbances, inflammation, cell death and proliferation, are changes that may occur individually in gills for several reasons (Ferguson 1989), but the combined presentation of these observed changes is, to the best of our knowledge, different from other gill dis- 
eases previously described. PGI may therefore be regarded as a distinct disease. ASPV was detected by immunostaining of epithelial and endothelial cells of pathologically altered tissues, and not found in apparently normal tissues. This association of ASPV with tissue damage demonstrates that the virus is at least a contributing cause of the disease.

Further, ASPV was neither detected in the gills of all the fish nor at all locations with gill vascular and epithelial changes, indicating that the detection meth-

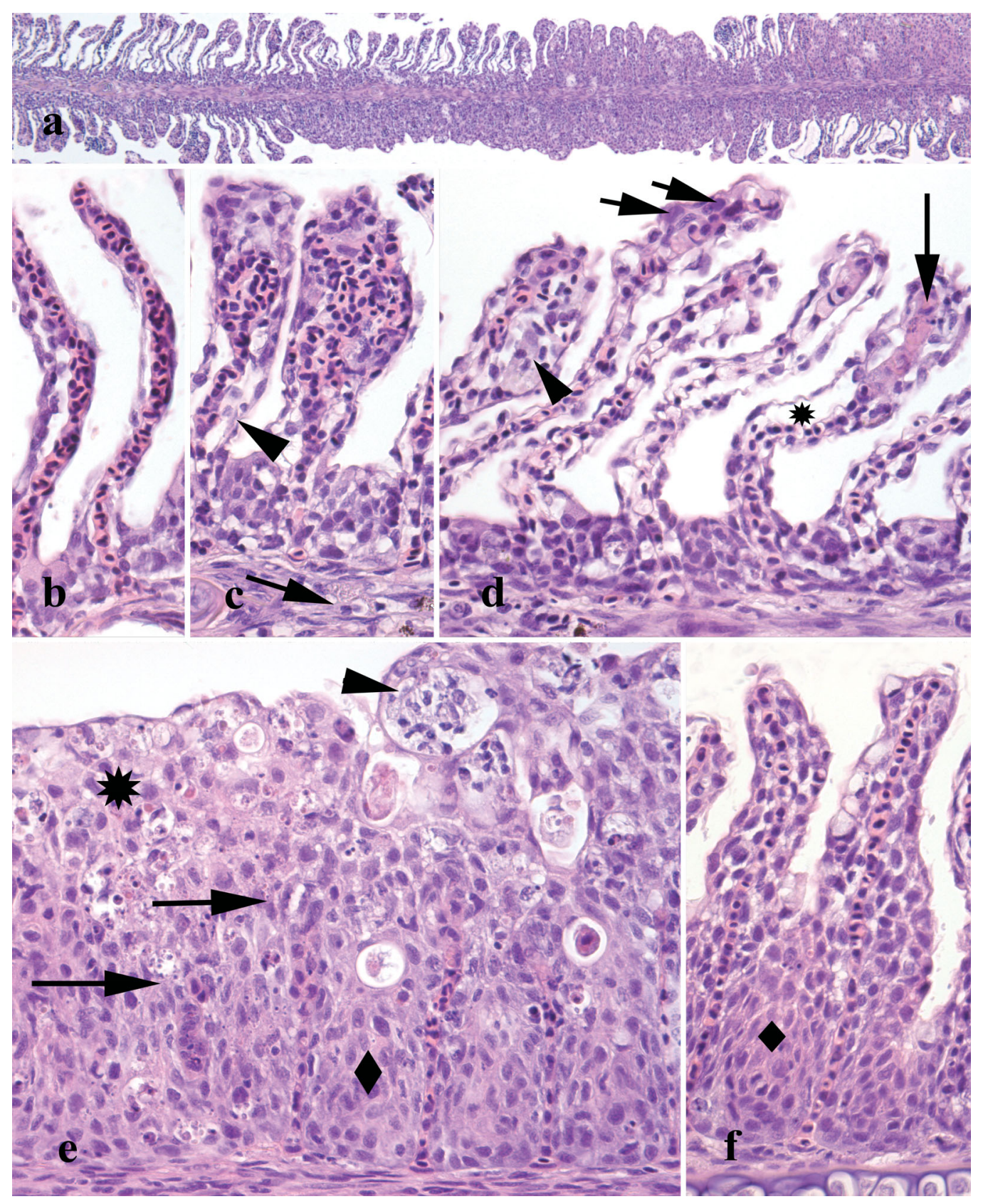

Fig. 2. Salmo salar L. Atlantic salmon with proliferative gill inflammation (PGI). Haemalum and eosin stained section of formalinfixed and paraffin-embedded gill. (a) $\times 50,(b-g) \times 305$. (a) One filament with extensive proliferation as the most prominent change in its distal part (right) and many thickened lamellae in the proximal part (left). (b) Lamellae with extensive erythrocyte accumulation in capillary lumina. (c) Lamellae with haemorrhages. Few inflammatory cells were present in the epithelium (arrowhead) and centrally in the filament (arrow). (d) Lamellae with death of endothelial (pillar) cells and thrombosis (long arrow), and basally in epithelium oedema (asterisk) and inflammatory cells (arrowhead). A few epitheliocystis inclusions in 1 lamella (short arrows). (e) Two previous lamellae with apparent disappearance of vascular system above the positions of the arrows. Extensive epithelial proliferation (diamond), remnants of many necrotic cells (asterisk) and inflammatory cells in distended lumen of the marginal channel in a lamella (arrowhead). (f) Epithelial proliferation especially in interlamellar epithelium (diamond) and along lamellae where inflammatory cells are also present 
Table 1. Salmo salar L. Atlantic salmon paramyxovirus (ASPV) and epitheliocystis inclusions detected in gills of $S$. salar with proliferative gill inflammation (PGI). Gills from selected fish were examined in parallel by indirect immunofluorescence (IIF) on cryosections, histology and immunohistochemistry (IHC) on sections from formalin-fixed and paraffin-embedded tissue

\begin{tabular}{|lccc|}
\hline Farm & $\begin{array}{c}\text { No. of } \\
\text { fish } \\
\text { examined }\end{array}$ & $\begin{array}{c}\text { No. of fish in which } \\
\text { ASPV was detected } \\
\text { by immunostaining }\end{array}$ & $\begin{array}{l}\text { No. of fish in which } \\
\text { epitheliocysts were } \\
\text { detected by histology }\end{array}$ \\
\hline 1 & 10 & 5 (IIF: 2, IHC: 5) & 6 \\
2 & 12 & 5 (IIF: 5, IHC: 2) & 2 \\
3 & 27 & 12 (IIF: 11, IHC: 1 ) & 11 \\
a Total number (number detected by methods indicated) & \\
\hline
\end{tabular}

ods were not sufficiently sensitive, that the viral antigens had disappeared when these fish were sampled late in the disease outbreaks, or that other agents were responsible for the tissue changes. The aetiological significance of chlamydia-like bacteria for the development of these changes is also uncertain, as these bacteria can only be detected late in infection when they have formed cysts detectable by histology. Nevertheless, the detection of ASPV and/or chlamydia-like bacteria or none of these agents in gills with PGI demonstrates its multifactorial and partly unsolved aetiology.

Results from the characterization studies of ASPV (Kvellestad et al. 2003) provide a basis for the understanding of the results reported in this paper, as will be highlighted in the following discussion.

The immunostaining observed in cells from cultures and tissues was similar and came from all parts of the cytoplasm and probably also plasma membrane. No nuclear staining was observed. Fluorescence from many small particles in the cytoplasm of cultured cells stained $7 \mathrm{~d}$ p.i. is consistent with the presence of viral components in the cytoplasm and budding of large virions from the plasma membrane. The more homogenous fluorescence from all parts of the cytoplasm in cells stained $14 \mathrm{~d}$ p.i. is consistent with the continued presence of viral components in the plasma membrane and cytoplasm of shrunken inclusion-containing cells no longer releasing virions. As fluorescence in cell cultures was associated with CPE, the immunohistochemical reactions in gill tissue could be related to pathological changes, including cell death. The infection of lamellar endothelial cells implies that their plasma membranes were covered with haemagglutinin which has the ability to adsorb erythrocytes. If this occurred at the plasma membranes facing the lumina of the vessels, it could explain the erythrocyte accumulation observed in lamellar vessels. Likewise, the death of these endothelial cells may induce the haemorrhages and thromboses observed.
The pathological changes result in impaired gill function due to reduced surface area, impeded blood flow, increased distance between blood and water, and loss of cells necessary for gill function (Ferguson 1989, Roberts $\&$ Rodger 2001). The extensive inflammation also indicates an increased activity of haematopoietic tissue.

Mean water temperatures ranging from $17^{\circ} \mathrm{C}$ in August to $12^{\circ} \mathrm{C}$ in September in Farm 1 were similar to those in Farms 2 and 3 and are within the temperature range 6 to $21^{\circ} \mathrm{C}$ observed for in vitro replication of ASPV. The slow in vitro replication rate observed for ASPV may also explain the long duration of disease outbreaks observed in the fish farms. The occurrence of virus in association with acute vascular changes, i.e. haemorrhage and thrombosis, and with chronic reactive changes of the epithelium, i.e. hyperplasia and infiltration with inflammatory cells, in one and the same fish also indicate a protracted disease course at the individual level.

To the best of our knowledge, this is the first report of a fish disease related to infection with a member of the Paramyxoviridae. Isolations of paramyxo-like viruses from chinook salmon (Winton et al. 1985) and carp (Body et al. 2000) also indicate that this virus family is represented among fish pathogens. The detection of ASPV in epithelial and endothelial cells is consistent with the properties of a number of paramyxoviruses that can initiate systemic infection following primary replication in the respiratory mucosa of man and of warm-blooded animals (Tyler \& Nathanson 2001).

In conclusion, ASPV has been detected by cell culture isolation and by immunostaining in gills of Atlantic salmon with PGI. It is therefore concluded that ASPV is at least a contributing cause of PGI, and its significance as an aetiological agent of PGI and possibly other diseases of unsolved aetiology should be further investigated. The apparent multifactorial aetiology of PGI recommends an epidemiological approach including the use of more sensitive methods to detect ASPV and chlamydia-like bacteria in tissues. An infectivity challenge model with ASPV should also be established for the study of pathogenesis, especially to clarify whether the gills are the primary site of replication, and to sequentially describe the development of pathological changes in gills and possibly also other organs.

Acknowledgements. This work was funded by the Norwegian Research Council and directed by Prof. Dr. Trygve T. Poppe at the Norwegian School of Veterinary Science. The authors are 
indebted to the farmers involved. The cells were kindly supplied by Dr. Lucy E. J. Lee at the University of Saskatchewan. We are grateful to Dr. Niels Jørgen Olesen, Danish Veterinary Laboratory, Aarhus, Denmark and Dr. Scott LaPatra, Clear Spring Foods, Corporative Office, Idaho, USA, for providing formalin-fixed specimens from verified outbreaks of VHS and IHN, respectively. We also thank the following staff members of the Norwegian School of Veterinary Science: May-Britt Gåsholm and Birgit Røe for preparing histologic sections, Dr. Adrian Smith for immunization of rabbit, and the library for valuable assistance; and the following staff of the National Veterinary Institute: Randi Terland, Hilde Welde and Marianne Heum for technical assistance, Dr. Ole Bendik Dale for sections from verified outbreaks of IPN and ISA, and Dr. Duncan Colquhoun for language correction.

\section{LITERATURE CITED}

Body A, Lieffrig F, Charlier G, Collard A (2000) Isolation of virus-like particles from koi (Cyprinus carpio) suffering gill necrosis. Bull Eur Assoc Fish Pathol 20:87-88

Bols NC, Barlian A, Chirino-Trejo M, Caldwell SJ, Goegan P, Lee LEJ (1994) Development of a cell line from primary cultures of rainbow trout, Oncorhynchus mykiss (Walbaum), gills. J Fish Dis 17:601-611

Brudeseth BE, Castric J, Evensen $\varnothing$ (2002) Studies on pathogenesis following single and double infection with viral hemorrhagic septicemia virus and infectious hematopoietic necrosis virus in rainbow trout (Oncorhynchus mykiss). Vet Pathol 39:180-189

Draghi A II, Popov VL, Kahl MM, Stanton JB, Brown CC, Tsongalis GJ, West AB, Frasca S Jr (2004) Characterization of 'Candidatus piscichlamydia salmonis' (order Chlamydiales), a chlamydia-like bacterium associated with epitheliocystis in farmed Atlantic salmon (Salmo salar). J Clin Microbiol 42:5286-5297

Evensen $\varnothing$ (1993) An immunohistochemical study on the cytogenetic origin of pulmonary multinucleate giant cells in porcine dermatosis vegetans. Vet Pathol 31:162-170

Evensen Ø, Rimstad E (1990) Immunohistochemical identification of infectious pancreatic necrosis virus in paraffinembedded tissues of Atlantic salmon (Salmo salar L). J Vet Diagn Invest 2:288-293

Evensen Ø, Meier W, Wahli T, Olesen NJ, Vestergård Jørgensen PE, Håstein T (1994) Comparison of immunohistochemistry and virus cultivation for detection of viral hemorrhagic septicaemia virus in experimentally infected rainbow trout Oncorhynchus mykiss. Dis Aquat Org 20: 101-109

Falk K, Dannevig BH (1995) Demonstration of infectious salmon anaemia (ISA) viral antigens in cell cultures and tissue sections. Vet Res 26:499-504

Editorial responsibility: Jo-Ann Leong, Kaneohe, Hawaii, USA
Falk K, Namork E, Rimstad E, Mjaaland S, Dannevig BH (1997) Characterization of infectious salmon anemia virus, an orthomyxo-like virus isolated from Atlantic salmon (Salmo salar L.). J Virol 71:9016-9023

Ferguson HW (1989) Systemic pathology of fish, 1st edn. Iowa State University Press, Ames, IA

Harlow E, Lane D (1988) Antibodies, a laboratory manual. Cold Spring Harbor Laboratory, New York

Hoffman GL, Dunbar CE, Wolf K, Zwillenberg LO (1969) Epitheliocystis, a new infectious disease of the bluegill (Lepomis macrochirus). Antonie Leeuwenhoek 35: 146-158

Hsu SM, Raine L, Fanger H (1981) Use of an avidin-biotinperoxidase complex $(\mathrm{ABC})$ in immunoperoxidase techniques: a comparison between $\mathrm{ABC}$ and unlabelled antibody (PAP) procedures. J Histochem Cytochem 29: 577-580

Kvellestad A, Dannevig BH, Falk K (2003) Isolation and partial characterization of a novel paramyxovirus from the gills of diseased seawater-reared Atlantic salmon (Salmo salar L.). J Gen Virol 84:2179-2189

Kvellestad A, Aarflot L, Tørud B, Holm JA (2004) Proliferativ gjellebetennelse hjå laks - eit undervurdert problem? (Proliferative gill inflammation in Atlantic salmon-an underestimated problem?). Norsk Veterinærtidsskrift 116: 552-553 (in Norwegian)

Nygaard SMR (2000) Gjellesykdommen epiteliocystis i sjø (The gill disease epitheliocystis in seawater). Norsk Fiskeoppdrett 4:34-36 (in Norwegian)

Nygaard SMR, Flesjå K (1997) Epitheliocystis in Atlantic salmon - an epidemiological study. Eur Assoc Fish Pathol: 8th Int Conf Fish Shellfish Dis, Edinburgh, P-059

Nylund A, Kvenseth AM, Isdal E (1998) A morphological study of the epitheliocystis agent in farmed Atlantic salmon. J Aquat Anim Health 10:43-55

Roberts RJ, Rodger HM (2001) The pathophysiology and systematic pathology of teleosts. In: Roberts RJ (ed) Fish pathology. WB Saunders, London, p 55-132

Shi SR, Chaiwun B, Young L, Cote RJ, Taylor CR (1993) Antigen retrieval technique utilizing citrate buffer or urea solution for immunohistochemical demonstration of androgen receptor in formalin-fixed paraffin sections. J Histochem Cytochem 41:1599-1604

Stevens A (1990) Pigments and minerals. In: Bancroft JD, Stevens A (eds) Theory and practice of histological techniques. Churchill Livingstone, Edinburgh, p 245-267

Tyler KL, Nathanson N (2001) Pathogenesis of viral infections. In: Knipe DM, Howley PM, Griffin DE, Martin MA, Lamb RA, Roizman B (eds) Fields virology. Lippincott Williams \& Wilkins, Philadelphia, PA, p 199-243

Winton JR, Lannan CN, Ransom DP, Fryer JL (1985) Isolation of a new virus from Chinook salmon (Oncorhynchus tshawytscha) in Oregon USA. Fish Pathol 20:373-380

Submitted: September 10, 2004; Accepted: June 13, 2005

Proofs received from author(s): November 2, 2005 